Original Research

\title{
Polyplexes of retinoic acid: an in vitro study of complex nanostructures against colorectal cancer cell line (HCT-15)
}

\author{
Narayan Ture ${ }^{1} \cdot$ Drashti Desai $^{1} \cdot$ Pravin Shende $^{1}$ \\ Received: 20 November 2020 / Accepted: 7 June 2021 / Published online: 14 September 2021 \\ (c) The Author(s) 2021
}

\begin{abstract}
Despite recent advances in the treatment of human colon cancer, the chemotherapeutic efficacy against colon cancer is still unsatisfactory. The complexity in colorectal cancer treatment leads to new research in combination therapy to overcome multidrug resistance in cancer and increase apoptosis. The objective of the present research work was to develop polyplexes for co-delivery of plasmid DNA with retinoic acid against colorectal cancer cell line (HCT-15). Plain polyplexes were prepared using chitosan and hyaluronic acid solution $(0.1 \% \mathrm{w} / \mathrm{v})$, whereas retinoic acid polyplexes were prepared using ethanol: water $(1: 9 \mathrm{v} / \mathrm{v})$ system. The particle size was observed in the order of chitosan solution $>$ blank polyplex $>$ retinoic acid-loaded polyplex. Encapsulation efficiency of retinoic acid was found to be $81.51 \pm 4.33 \%$ for retinoic acid-loaded polyplex formulation. The drug release was observed to be in a controlled pattern with $72.23 \pm 1.32 \%$ release of retenoic acid from polyplex formulation. Cell line studies of the formulation displayed better cell inhibition and low cytotoxicity for the retinoic acid-loaded polyplexes in comparison to pure retinoic acid, thus demonstrating better potential action against colorectal cancer cell line HCT-15. Retinoic acid-loaded polyplexes indicated higher potential for the delivery of the active whereas the cell line studies displayed the efficacy of the formulation against colorectal cancer cell line HCT-15.
\end{abstract}

\section{Graphical Abstract}

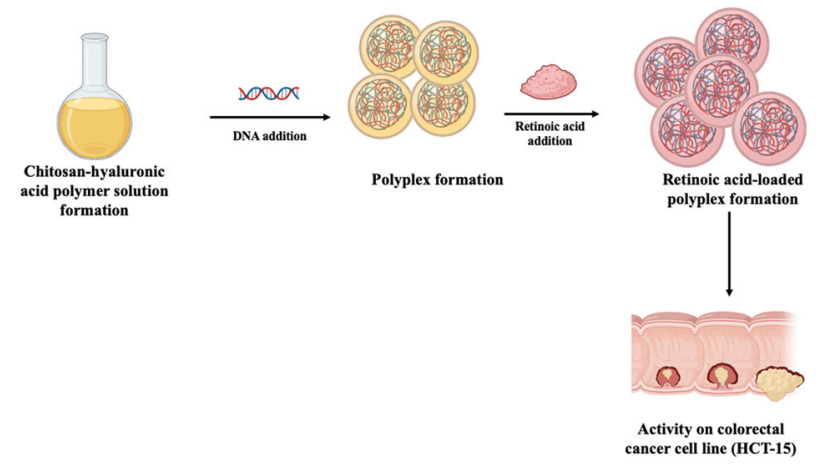

Pravin Shende

shendepravin94@gmail.com

1 Shobhaben Pratapbhai Patel School of Pharmacy and Technology Management, SVKM'S NMIMS, V. L. Mehta Road, Vile Parle (W), Mumbai, India

\section{Introduction}

According to the latest statistical studies, colorectal cancer (CRC) stands third most common cancer worldwide after blood and lung cancers [1]. Numerous initiatives like theranostics and chemotherapy are mainly adopted for the treatment, but still the mortality rate of $\mathrm{CRC}$ is more. Chemotherapy is one of the commonly used therapies to treat cancer, however, the risk of adverse effects like nausea, 
vomiting, headache, alopecia, etc. is accompanied with the treatment. Recent advances in nanotechnology target cancer cells using cytotoxic drugs without affecting normal cells [2]. Over the last few years, several types of drug-loaded nanoparticulate systems like liposomes, dendrimers, polyplexes and micelles in the size range of $20-400 \mathrm{~nm}$ showed a strong impact for delivery of drug in chemotherapy [3]. Nevertheless, despite of high morbidity and mortality associated with CRC, the clinical development of nanoparticles for treatment remains limited. Diverse shapes, sizes and chemical natures of nanoparticles demonstrate high efficacy for encapsulating different types of anticancer therapeutics including siRNA, antibiotics, chemotherapeutics, proteins and peptides. Traditional cytotoxic agents for CRC cause several side effects like renal failure because of current therapeutic protocols based on a series of repeated administration. Recent trends in nanomedicine include the use of combined therapy of cytotoxic drugs loaded with nanocarriers to offer prolonged release, sitespecific delivery and reduction or elimination of first-pass metabolism. Polymer-based nanoparticulate systems like polymer nanocapsules, polymeric mesoporous nanoparticles, nanogels, polyplexes, polymer-lipid hybrid nanosystems, polymer-drug/protein complex, polymeric dendrimers, etc. are considered for improvement of bioavailability of antineoplastic agents []. The combined therapy also includes DNA or RNA to assemble the nanoparticles for the expression or knockdown of genes to enhance the effectiveness of cytotoxic drugs like cisplatin, doxorubicin, etc. Cationic polymers such as chitosan (CS), poly(allylamine hydrochloride), polyethylenimine, etc. are commonly considered for the linkage of DNA with the polymeric matrix for enhancing the activity and stability [4]. Due to the presence of surface charges (SCs), polyplexes offer effective complexation with genetic materials viz. siRNA for gene therapy, DNA for cancer therapy, etc. Polyplexes are polymeric complex of active to increase the solubility, delay the degradation step and offer site-specific action [5, 6]. The adaptable structure enables the active to form complex linkage with polymers like polyethyleneimine and poly-l-lysine for controlled release pattern [7]. Due to proper polymeric composition and SC, polyplexes are considered as an ideal nanocarrier for the delivery of nucleic acids. Retinoic acid is a derivative of vitamin A which is present in the body that aids to inhibit CRC in mice and humans by acting on different signalling pathways for cell proliferation and growth inhibition [8]. Retinoic acid emerges as a good chemotherapeutic and chemopreventive agent because of its differentiation, antiproliferative, pro-apoptotic and antioxidant effects [9]. CRC demonstrated the presence of high levels of protein in the intestinal tissues and expressed poor degradation of retinoic acid in comparison to healthy individual. Using externally supplemented retinoic acid in the intestine or blocking the enzyme degradation significantly reduce the burden of cancer growth in the patients [10].
The objective of the present research work was to develop polyplexes for co-delivery of plasmid DNA with retinoic acid against CRC cell line (HCT-15).

\section{Materials and methods}

\subsection{Materials}

Retinoic acid was procured from Tokyo chemical industry, Japan. Plasmid DNA and hyaluronic acid were obtained from RL Chem Industries, India. HCT-15 human cell line was purchased from National Centre for Cell Sciences, Pune, India. All other reagents were of analytical grade and used without further purification.

\subsection{Methods}

\subsubsection{Formulation of chitosan (CS)-hyaluronic acid (HA) polyplexes}

$0.02 \% \mathrm{~W} / \mathrm{v}$ CS solution was prepared with $0.1 \mathrm{M}$ acetic acid by maintaining the $\mathrm{pH} 3.5$ and sodium sulphate solution $(5.0 \mathrm{mM})$ was individually pre-heated at $60^{\circ} \mathrm{C}$. CS solution of equal volume was added to sodium sulphate solution; the solution was vortexed for $30 \mathrm{~s}$ and submerged in an ice bath to maintain the temperature at $5{ }^{\circ} \mathrm{C}$. $0.1 \% \mathrm{w} / \mathrm{v}$ HA solution was added to $5 \mathrm{mM}$ sodium sulphate and CS mixture. To formulate CS and CSHA polyplexes with pDNA, ratio of $\mathrm{PO}_{4}: \mathrm{NH}_{3}$ group as 1:5 of $\mathrm{CS}$ and pDNA was used (Table 1). pDNA was added to sodium sulphate and CS solutions for the formation of polyplexes [11]. The blank CS polyplexes were prepared by the same procedure described above without addition of retinoic acid.

\subsubsection{Preparation of retinoic acid polyplexes}

The retinoic acid was added in ethanol: water system $(1: 9 \mathrm{v} / \mathrm{v})$ and subsequently mixed with sodium sulphate solution. Finally, CS and retinoic acid solutions were mixed and vortexed for $50 \mathrm{~s}$ for the formation of retinoic acid-loaded polyplexes [12] and abbreviated as P1, P2, P3 and P4 (Table 1).

Table 1 Compositions of different formulations of polyplexes

\begin{tabular}{lllll}
\hline & \multicolumn{4}{l}{ Formulation } \\
\cline { 2 - 5 } Ingredient & $\mathrm{P} 1$ & $\mathrm{P} 2$ & $\mathrm{P} 3$ & $\mathrm{P} 4$ \\
\hline Hyaluronic acid & $1 \mathrm{mg}$ & $1 \mathrm{mg}$ & $1 \mathrm{mg}$ & $1 \mathrm{mg}$ \\
Chitosan & $2 \mathrm{mg}$ & $2 \mathrm{mg}$ & $2 \mathrm{mg}$ & $2 \mathrm{mg}$ \\
Sodium sulphate & $0.7 \mathrm{~g}$ & $0.7 \mathrm{~g}$ & $0.7 \mathrm{~g}$ & $0.7 \mathrm{~g}$ \\
DNA & - & - & $50 \mu \mathrm{g}$ & $50 \mu \mathrm{g}$ \\
Retinoic acid & - & $1 \mathrm{mg}$ & - & $1 \mathrm{mg}$ \\
\hline
\end{tabular}




\subsection{Characterisation of polyplexes}

\subsubsection{Particle size and SC}

The measurements of particle size and SC of polyplex (formulations $\mathrm{P} 1-\mathrm{P} 4$ ) were obtained by dispersing the samples in distilled water at $25^{\circ} \mathrm{C}$ using Malvern Zetasizer (Nano ZS90, UK) [13].

\subsection{2 \% Encapsulation efficiency (EE)}

Retinoic acid-loaded polyplexes formulations (P2 and P4) were accurately weighed and centrifuged in $10 \mathrm{~mL}$ measuring tubes for $20 \mathrm{~min}$ at $5000 \mathrm{rpm}$. The supernatant was collected and estimated for absorbance at $349 \mathrm{~nm}$ using UV-Visible spectrophotometer (Shimadzu, Japan).

The \% EE was calculated using following formula:

$$
\begin{aligned}
\% \mathrm{EE}= & \text { (Total amount of retinoic acid in polyplexes }- \\
& \text { Amountofretinoic acid in the supernatant } / \\
& \text { Total amount of retinoic acid in polyplexes }) \times 100 .
\end{aligned}
$$

\subsubsection{In vitro release study}

The polyplex formulations P2 and P4 were placed individually in a previously soaked dialysis membrane (Himedia, India). After adding formulation to dialysis bag, it was tied from both the ends and placed in $30 \mathrm{~mL}$ of phosphate buffer saline $\mathrm{pH} 7.4$ on a magnetic stirrer with a speed of $150 \mathrm{rpm}$ at $37^{\circ} \mathrm{C}$. Aliquots were withdrawn at pre-determined time intervals of $1,2,4,8$ and $24 \mathrm{~h}$ and sink condition was maintained with fresh phosphate buffer saline solution of $\mathrm{pH}$ 7.4. Aliquots were analysed using UV-visible spectrophotometer at the wavelength $349 \mathrm{~nm}$ [14].

Based on the particle size, SC, \% EE and in vitro release studies, formulations P3 and P4 were considered for further characterisation.

\subsubsection{Transmission electron microscopy (TEM)}

The morphological examinations of polymeric solution and polyplex formulations P3 and P4 were performed by TEM (JEOL JEM-1011 electron microscope). The freshly prepared formulations were placed on copper grids for few minutes, then air-dried and stained with phosphotungstic acid $(2 \% \mathrm{w} / \mathrm{v})$ before examination.

\subsubsection{FTIR spectroscopy}

FTIR spectra of HA, retinoic acid and formulations P3 and P4 were analysed using potassium bromide $(\mathrm{KBr})$ pellet method. The samples were analysed from 400 to $4000 \mathrm{~cm}^{-1}$ at $25^{\circ} \mathrm{C}$ with 32 scans using FTIR spectroscopy (Perkin Elmer, USA).

\subsubsection{Gel electrophoresis}

HA/CS-plasmid DNA polyplex formulations P3 and P4 were analysed using agarose gel electrophoresis. The polyplex formulations and naked plasmid DNA (average size $2 \mathrm{~kb}$ ) were loaded onto $1 \%$ agarose gel with ethidium bromide in Tris-borate EDTA buffer at $\mathrm{pH}$ 8. The formulations P3 and P4 were placed on the gel at $120 \mathrm{~V}$ for $30 \mathrm{~min}$ and photographed using Alpha Innotech, USA [15].

\subsubsection{In vitro cell cytotoxicity study}

In vitro studies for drug and formulations P1 to P4 on CRC cell lines HCT-15 were carried out by inoculating in 96well microtiter plates with a capacity of $100 \mu \mathrm{L}$ using MTT assay. The plate was supplemented with DMEM and $10 \%$ FBS along with samples dissolved in DMSO (100 mg/mL), diluted further to achieve $1 \mathrm{mg} / \mathrm{mL}$ using distilled water to obtain a serial concentrations of $100 \mu \mathrm{g} / \mathrm{mL}, 200 \mu \mathrm{g} / \mathrm{mL}$, $400 \mu \mathrm{g} / \mathrm{mL}, 800 \mu \mathrm{g} / \mathrm{mL}$ and aliquots of $10 \mu \mathrm{L}$ and added later to the microtiter wells of $90 \mu \mathrm{L}$ of medium and the final active concentration was of $10 \mu \mathrm{g} / \mathrm{mL}, 20 \mu \mathrm{g} / \mathrm{mL}$, $40 \mu \mathrm{g} / \mathrm{mL}$ and $80 \mu \mathrm{g} / \mathrm{mL}$. The plate was incubated at $37^{\circ} \mathrm{C}$ with $5 \% \mathrm{CO}_{2}, 95 \%$ air and $100 \% \mathrm{RH}$ for $24 \mathrm{~h}$. The plate was read at $570 \mathrm{~nm}$ to obtain the absorbance by conversion of MTT to formazan used to calculate the cell growth concentrations using given formula [16-19].

$\%$ Growth inhibition $=($ Different concentrations of test growth in the presence of different drug/Concentration of control growth) $\times 100 \%$

\section{Results}

\subsection{Particle size and SC}

The particle size and SC of formulations P1 to P4 are shown in Table 2 where the polyplexes (formulations P1-P4) were found to be in the range between $284.9 \pm 31.23 \mathrm{~nm}$ to $526.4 \pm$ $94.25 \mathrm{~nm}$. Polyplex formulations P1 and P2 without plasmid

Table 2 Particle size and SC of formulations P1 to P4

\begin{tabular}{lccc}
\hline Formulation & Particle size $(\mathrm{nm} \pm$ S.D. $)$ & $\mathrm{SC}(\mathrm{mV} \pm$ S.D. $)$ & PDI \\
\hline P1 & $284.9 \pm 31.23$ & $15.8 \pm 0.14$ & 0.273 \\
P2 & $427.35 \pm 40.57$ & $21.7 \pm 0.23$ & 0.266 \\
P3 & $341.5 \pm 70.45$ & $19.35 \pm 0.58$ & 0.245 \\
P4 & $526.4 \pm 94.25$ & $18.27 \pm 0.47$ & 0.160 \\
\hline
\end{tabular}


DNA showed the particle size $284.9 \pm 31.23 \mathrm{~nm}$ and $427.35 \pm 40.57 \mathrm{~nm}$, respectively, while those preparations formulated with plasmid DNA in the form of formulations P3 and P4 revealed the size of $341.5 \pm 70.45 \mathrm{~nm}$ and $526.4 \pm$ $94.25 \mathrm{~nm}$, respectively. The particle size of the polyplexes depends on the molecular weight of the anionic polymer and it also influences the morphology of polyplexes structures. The zeta potential of polyplexes showed cationic charges in the range of $15.23 \pm 5.47 \mathrm{mV}$ to $24.37 \pm 4.32 \mathrm{mV}$ and indicated better colloidal stability [20]. The particle size showed strong interaction of CS with negatively charged plasmid DNA to increase the large chain entanglement and produce nano-dimensional polyplexes. An average PDI value below 0.3 represented homogeneous distribution of all the formulations of polyplex. Slight increase in particle size and decrease in SC were observed due to the presence of HA.

\section{$3.2 \%$ EE}

Formulations P2 displayed \% EE of retinoic acid of $72.25 \pm$ $3.42 \%$, whereas formulation $\mathrm{P} 4$ showed $81.51 \pm 4.33 \%$, and statistically analysed using Student's $t$ test with significant values on addition of pDNA (Fig. 1). Thus, loading of retinoic acid depends on the ratio of drug and polymer possessing positive effect. The presence of CS in polyplexes provided high encapsulation efficiency of DNA whereas the encapsulation of drug into polyplex structure showed an association of cations of chitosan and anions of drug molecules. Moreover, hydrophobic interactions or hydrogen bonds between the organic bases of the nucleotide and the sugar structure of polymer played important role in the stability. These results supported the hypothesis of multiple interactions between CS and pDNA.

\subsection{In vitro release study}

The formulation $\mathrm{P} 2$ displayed highest $\%$ retinoic acid release of $72.23 \pm 1.32 \%$ followed by $\mathrm{P} 4$ with the release of $65.43 \pm$ $3.14 \%$ for $24 \mathrm{~h}$ (Fig. 2). The in vitro study displayed maximum $\%$ release of retinoic acid within $2 \mathrm{~h}$, even though formulation P2 showed prolonged release for $24 \mathrm{~h}$ of retinoic acid due to its complexation with polymer. The difference in efficiency of percentage drug release by formulations P2 and P4 was not statistically significant as per Student's $t$ test ( $p$ value $<0.05$ ) [21]. This might be due to the strong interaction of CS with negatively charged pDNA in formulation $\mathrm{P} 4$ whereas in formulation P2, pDNA was not present.

\subsection{TEM}

TEM showed that formulations P3 and P4 formed heterogeneous populations of spherical, toroidal and oblong polyplexes. The TEM studies displayed that the formulation

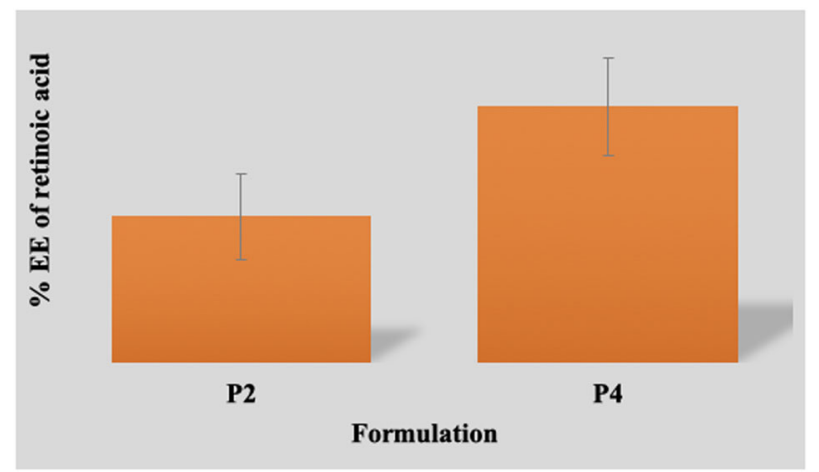

Fig. $1 \%$ EE of retinoic acid-loaded polyplex formulations. Data were analysed using Student's $t$ test $(* p<0.05)$ when compared with polyplex formulation without pDNA

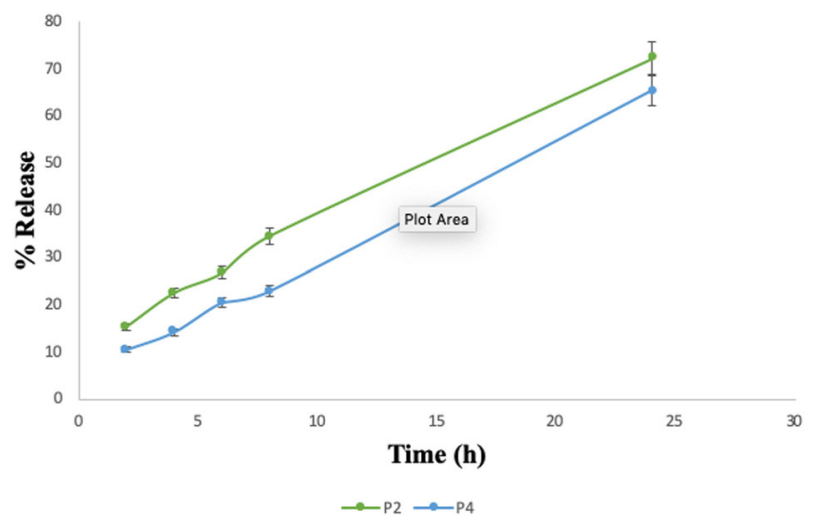

Fig. $2 \%$ Drug release profiles of retinoic acid from polyplex formulations $\mathrm{P} 2$ and $\mathrm{P} 4$

P3 showed aggregation of particles due to the incorporation of the HA into CS polyplex structure (Fig. 3).

\subsection{FTIR spectroscopy}

FTIR spectra confirmed the formation of polymer-DNA complex and drug-loaded polyplexes. FTIR spectrum of formulation P4 was compared with the retinoic acid as shown in Fig. 4. The spectrum of blank polyplex formulation (P3) exhibited the presence of CS and HA in the region of $3291-3161 \mathrm{~cm}^{-1}$ corresponds to the $\mathrm{N}-\mathrm{H}$ and $\mathrm{O}-\mathrm{H}$ stretching. The peaks at 1720 and $1648 \mathrm{~cm}^{-1}$ corresponded to carbonyl stretching of carboxylic acid and amide, respectively and indicated the presence of $\mathrm{HA}$ in the formulation. In FTIR studies, the major peaks at 1800-1500, $1500-1250$ and $1250-800 \mathrm{~cm}^{-1}$ in three regions confirmed the presence of DNA in the formulation P4.

\subsection{Gel electrophoresis}

The complexation and retention of plasmid DNA by polyplex formulations were evaluated using gel electrophoresis. 


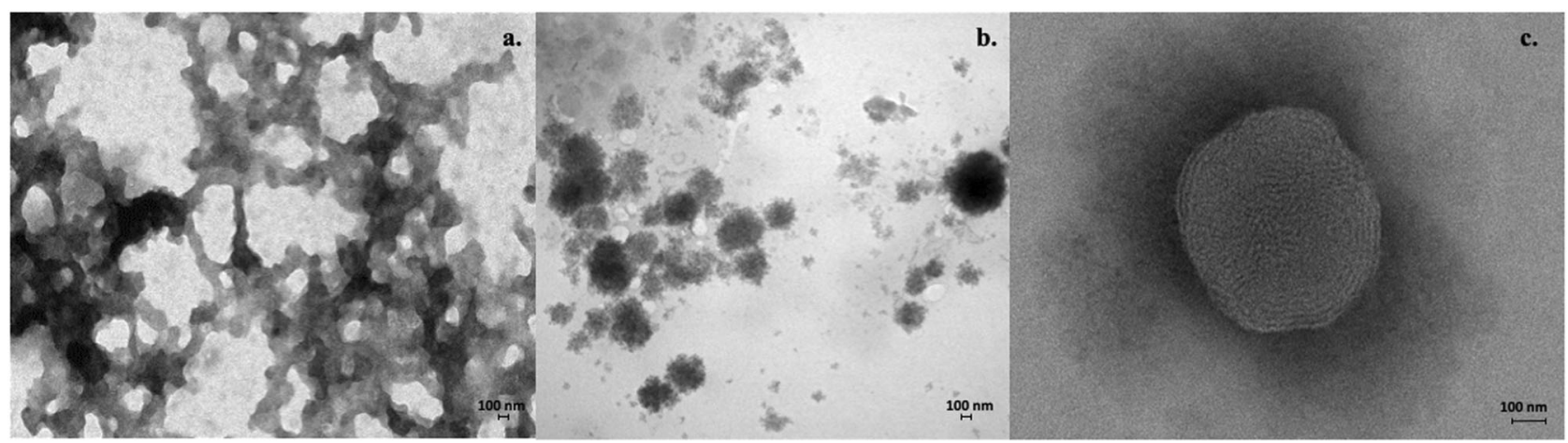

Fig. 3 TEM of (a) polymer solution, (b) formulation P3 and (c) formulation P4

Fig. 4 FTIR spectra of (a) hyaluronic acid, (b) chitosan solution and formulations, (c) P3 and (d) P4

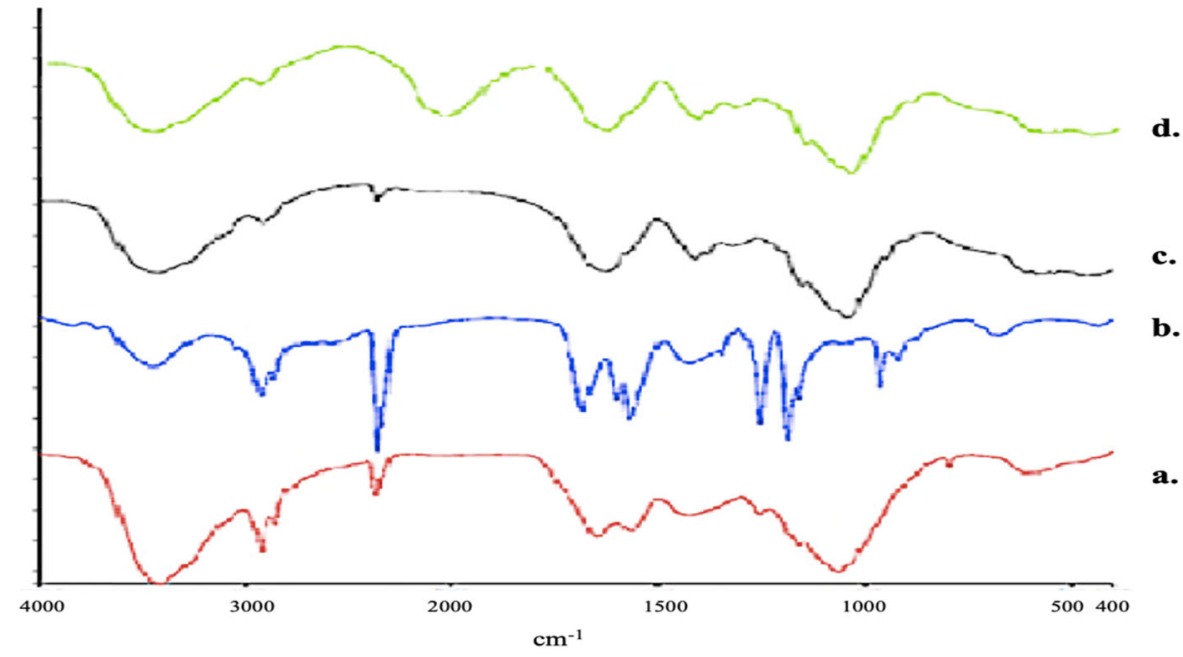

In agarose gel, formulations $\mathrm{P} 3$ and $\mathrm{P} 4$ at all concentrations showed no migration of pDNA signal at $2 \mathrm{~kb}$, indicating the effective and complete complexation with the polymer. All the formulations showed complexation with pDNA whereas absence of pDNA migration was observed in Fig. 5 $[22,23]$. There was no other free DNA band displayed, indicating a steric interaction between polymer and plasmid DNA [24, 25].

\subsection{In vitro cell cytotoxicity study}

For the assessment of cytotoxic action, formulations P1, P2, $\mathrm{P} 3$ and $\mathrm{P} 4$ were treated on HCT-15 cell lines using pDNA at collective $\mathrm{N} / \mathrm{P}$ ratios present in polyplex formulations $(2.5$, 5, 7.5, 10 and 12.5) where retinoic acid showed $\mathrm{IC}_{50}$ value of 5 and formulations P1, P2, P3 and P4 depicted $\mathrm{IC}_{50}$ values of 2, 6, 3.5 and 3, respectively at the concentration of $10 \mu \mathrm{g} / \mathrm{mL}$ [26]. As the formulation P1 contained no DNA or drug, it's $\mathrm{IC}_{50}$ value was found to be the lowest whereas formulation P3 contained pDNA which showed a minimal cytotoxic effect. On the other hand, the content of drug (retinoic acid) was more in formulation P2 compared to the mixture of DNA and retinoic acid in formulation $\mathrm{P} 4$, hence

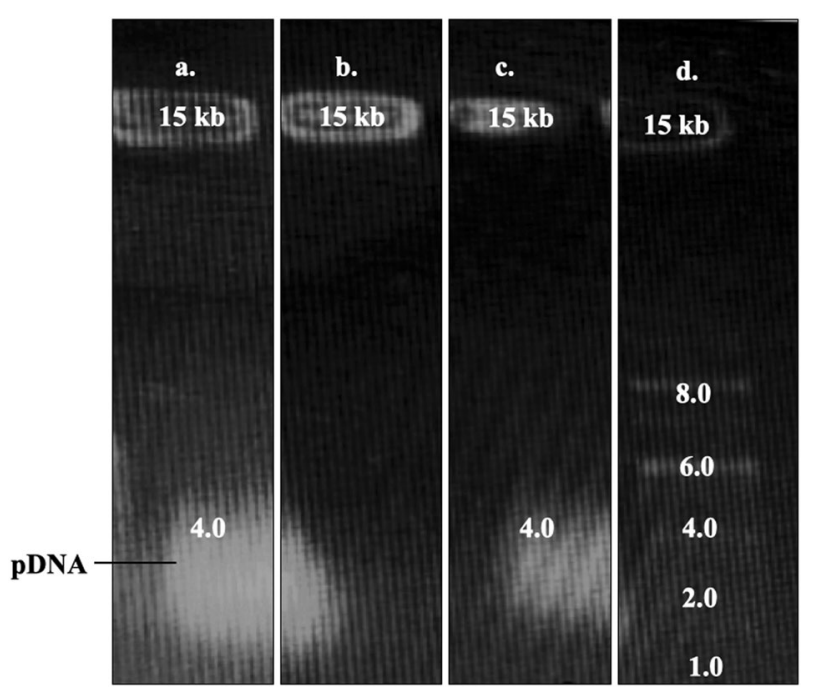

Fig. 5 Gel electrophoresis of (a) plasmid DNA, (b) formulation P3, (c) formulation P4 and (d) standard marker

it showed reduction in the $\mathrm{IC}_{50}$ value [27] . The percentage inhibition of HCT-15 cells was conducted on plain retinoic acid and formulations $\mathrm{P} 1$ to $\mathrm{P} 4$. The $\%$ inhibition was highest for $\mathrm{P} 4$ i.e. $99.02 \% \pm 0.024 \%$ and for formulation $\mathrm{P} 2$, 
Table 31 inhibition by drug and different formulations P1, P2, P3 and $\mathrm{P} 4$ at different concentrations

\begin{tabular}{|c|c|c|c|c|c|}
\hline \multirow[t]{2}{*}{ Sample } & \multirow[t]{2}{*}{$\mathrm{N} / \mathrm{P}$ ratio } & \multicolumn{4}{|c|}{$\%$ Cell inhibition } \\
\hline & & 1 & 2 & 3 & $\begin{array}{l}\text { Average }(\% \pm \mathrm{S} \text {. } \\
\text { D.) }\end{array}$ \\
\hline Retinoic acid & $15 \mu \mathrm{g} / \mathrm{mL}$ & 54.2 & 51.01 & 52.1 & $52.44 \pm 1.32$ \\
\hline \multirow[t]{5}{*}{ Formulation P1 } & 2.5 & 3.76 & 4.51 & 2.92 & $3.73 \pm 0.65$ \\
\hline & 5 & 7.43 & 9.11 & 6.34 & $7.63 \pm 1.14$ \\
\hline & 7.5 & 10.36 & 8.05 & 13.44 & $10.62 \pm 2.21$ \\
\hline & 10 & 13.75 & 10.97 & 12.51 & $12.41 \pm 1.14$ \\
\hline & 12.5 & 16.03 & 14.08 & 17.16 & $15.76 \pm 1.23$ \\
\hline \multirow[t]{5}{*}{ Formulation P2 } & 2.5 & 72.13 & 68.41 & 74.62 & $71.72 \pm 2.55$ \\
\hline & 5 & 76.73 & 78.63 & 75.15 & $76.84 \pm 1.42$ \\
\hline & 7.5 & 81.48 & 84.39 & 79.03 & $81.63 \pm 2.19$ \\
\hline & 10 & 89.23 & 86.25 & 91.06 & $88.85 \pm 1.98$ \\
\hline & 12.5 & 95.11 & 89.05 & 93.13 & $92.43 \pm 2.52$ \\
\hline \multirow[t]{5}{*}{ Formulation P3 } & 2.5 & 10.16 & 12.67 & 9.04 & $10.62 \pm 1.51$ \\
\hline & 5 & 15.78 & 18.02 & 17.93 & $17.24 \pm 1.03$ \\
\hline & 7.5 & 21.44 & 27.61 & 25.27 & $24.77 \pm 2.54$ \\
\hline & 10 & 39.07 & 37.13 & 32.36 & $36.19 \pm 2.81$ \\
\hline & 12.5 & 37.43 & 51.47 & 42.24 & $43.71 \pm 5.82$ \\
\hline \multirow[t]{5}{*}{ Formulation P4 } & 2.5 & 82.33 & 78.16 & 81.42 & $80.64 \pm 1.79$ \\
\hline & 5 & 86.07 & 88.14 & 84.52 & $86.24 \pm 1.48$ \\
\hline & 7.5 & 91.54 & 94.06 & 93.27 & $92.96 \pm 1.05$ \\
\hline & 10 & 95.24 & 92.35 & 97.06 & $94.88 \pm 1.94$ \\
\hline & 12.5 & 98.99 & 99.01 & 99.05 & $99.02 \pm 0.024$ \\
\hline
\end{tabular}

it was found to be $92.43 \% \pm 2.52 \%$ at $12.5 \mathrm{~N} / \mathrm{P}$ ratio (Table 3). The reported dose of retinoic acid is $60-90 \mathrm{mg}$ per day and more doses lead to adverse side effects like nausea, flaking skin, dry mouth, etc. but the use of polyplexes formulation displayed dose reduction and sitespecific action to the cancerous cells resulting in lower toxic effects as reported by Estevis and Varshosaz [28, 29]. Formulation P4 showed better cell inhibition at lesser dose $(10 \mu \mathrm{g} / \mathrm{mL})$ in comparison to retinoic acid for the treatment against HCT-15 cell line. Moreover, the formulation P2 contained $15 \mu \mathrm{g} / \mathrm{mL}$ of the drug which was higher than formulation P4 $(10 \mu \mathrm{g} / \mathrm{mL})$ consisting of drug and excipients with pDNA for providing the synergistic effect, leading to better cell inhibition.

\section{Discussion}

On the basis of evaluations tests like particle size, \% EE and in vitro drug release, formulation $\mathrm{P} 3$ without retinoic acid and formulation P4 containing retinoic acid, CS, HA, sodium sulphate and DNA were found to be suitable against CRC cell line HCT-15. Cross-linking reaction between HA and CS helped to slow the release of retinoic acid for $6 \mathrm{~h}$. Gel electrophoresis confirmed the complexation of pDNA in the form of polyplexes by demonstrating no migration in the band. The in vitro cell cytotoxicity study indicated that polyplexes displayed significant dose reduction in comparison to the recommended dose of retinoic acid for therapeutic application with significant cell inhibition. Hence, it is resulted that retinoic acid possesses the activity against HCT-15 cell growth at higher concentration $(15 \mu \mathrm{g} / \mathrm{mL})$ but on incorporation within polyplexes it showed similar inhibition activity on the HCT-15 cell line. This indicated better anticancer action at reduced concentration of retinoic acid by charge neutralisation of pDNA as well as polymer structure aiding the management of CRC by significant penetration of the polyplexes into the cell. Thus, the polyplex formulation inhibited the cancer growth and proposed for potential application in CRC.

\section{Conclusions}

The retinoic acid-loaded polyplexes were successfully formulated against CRC cell line HCT-15. The polyplex formulations were characterised by several parameters like particle size, SC, drug encapsulation, in vitro, gel electrophoresis and in vitro cell cytotoxicity studies. The network structure of the polymer solution and drug-loaded polyplex in the TEM analysis verified the formation of polyplex structure. Thus, the polyplexes act as a promising delivery against cancer cell line HCT-15 and also suggest as a new carrier in cancer therapy.

\section{Compliance with ethical standards}

Conflict of interest The authors declare no competing interests.

Publisher's note Springer Nature remains neutral with regard to jurisdictional claims in published maps and institutional affiliations.

Open Access This article is licensed under a Creative Commons Attribution 4.0 International License, which permits use, sharing, adaptation, distribution and reproduction in any medium or format, as long as you give appropriate credit to the original author(s) and the source, provide a link to the Creative Commons license, and indicate if changes were made. The images or other third party material in this article are included in the article's Creative Commons license, unless indicated otherwise in a credit line to the material. If material is not included in the article's Creative Commons license and your intended use is not permitted by statutory regulation or exceeds the permitted use, you will need to obtain permission directly from the copyright holder. To view a copy of this license, visit http://creativecommons. org/licenses/by/4.0/.

\section{References}

1. Peer D, Karp JM, Hong S, Farokhzad OC, Margalit R, Langer R. Nanocarriers as an emerging platform for cancer therapy. Nat Nanotechnol. 2007;2:751. 
2. Adil MM, Erdman ZS, Kokkoli E. Transfection mechanisms of polyplexes, lipoplexes, and stealth liposomes in $\alpha 5 \beta 1$ integrin bearing DLD-1 colorectal cancer cells. Langmuir. 2014;30:3802-10.

3. Schaffer DV, Fidelman NA, Dan N, Lauffenburger DA. Vector unpacking as a potential barrier for receptor-mediated polyplex gene delivery. Biotech Bioeng. 2000;67:598-606.

4. Conti M, Tazzari V, Baccini C, Pertici G, Serino LP, De Giorgi U. Anticancer drug delivery with nanoparticles. In Vivo.2006; 20:697-702.

5. Jafari M, Soltani M, Naahidi S, Karunaratne N, Chen D, Nonviral P. Approach for targeted nucleic acid delivery. Curr Med Chem. 2012;19:197-208.

6. Tros de Ilarduya C, Sun Y, Düzgüneş N. Gene delivery by lipoplexes and polyplexes. Eur J Pharm Sci. 2010;40:159-70.

7. Shende P, Ture N, Gaud RS, Trotta F. Lipid-and polymer-based plexes as therapeutic carriers for bioactive molecules. Int J Pharm. 2019;558:250-60.

8. Richard I, Thibault M, De Crescenzo G, Buschmann MD, Lavertu M. Ionization behavior of chitosan and chitosan-DNA polyplexes indicate that chitosan has a similar capability to induce a protonsponge effect as PEI. Biomacromolecules. 2013;14:1732-40.

9. Ma B, Zhang S, Jiang H, Zhao B, Lv H. Lipoplex morphologies and their influences on transfection efficiency in gene delivery. $\mathrm{J}$ Control Release. 2007;123:84-94.

10. Gebhar CL, Kabanov AV. Evaluation of polyplexes as gene transfer agents. J Control Release. 2001;73:401-16.

11. Tang MX, Szoka FC. The influence of polymer structure on the interactions of cationic polymers with DNA and morphology of the resulting complexes. Gene Ther. 1997;4:823-32.

12. Friend DS, Papahadjopoulos D, Debs RJ. Endocytosis and intracellular processing accompanying transfection mediated by cationic liposomes. Biochim Biophys Acta Biomembr. 1996;1278:41-50.

13. Horváth F, Sacchi M, Dombrádi E. A pannon-medence üledékeinek szeizmikus sztratigráfiai és tektonikai vizsgálata a dél-dunántúl és a balaton területén. Foldt Kozlony. 2010;140:391-418.

14. Desai D, Shende P. Drug-free cyclodextrin-based nanosponges for antimicrobial activity. J PharmInnov. 2020;16:258-268.

15. Midoux P, Breuzard G, Gomez JP, Pichon C. Polymer-based gene delivery: a current review on the uptake and intracellular trafficking of polyplexes. Curr Gene Ther. 2008;8:335-52.

16. Doye V, Hurt E. From nucleoporins to nuclear pore complexes. Curr Opin Cell Biol. 1997;9:401-11.

17. Von Gersdorff K, Sanders NN, Vandenbroucke R, De Smedt SC, Wagner E, Ogris $M$. The internalization route resulting in successful gene expression depends on both cell line and polyethylenimine polyplex type. Mol Ther. 2016;14:745-53.

18. Riss TL, Moravec RA, Niles AL, Duellman S, Benink HA, Worzella TJ, et al. Cell viability assays. Assay Guidance Man. 2016.

19. Pellissari CV, Vergani CE, Longo E, Pavarina AC, Sanitá PV, Siqueira WL, et al. In vitro toxic effect of biomaterials coated with silver tungstate or silver molybdate microcrystals. J Nanomaterials. 2020;2020:2971827.

20. Soumya K, James J, Archana TM, Dhanya AT, Shahid AP, Sudheesh S. Cytotoxic and antigenotoxic properties of phenolic compound isolated from the fruit of Terminalia chebula on HeLa cell. Beni-Suef Univ J Basic Appl Sci. 2019;8:1-6.

21. Joseph E, Singhvi G. Multifunctional nanocrystals for cancer therapy: a potential nanocarrier. Nanomaterials for drug delivery and therapy. 2019:91-116.

22. Clayton KN, Salameh JW, Wereley ST, Kinzer-Ursem TL. Physical characterization of nanoparticle size and surface modification using particle scattering diffusometry. Biomicrofluidics. 2016;10:054107.

23. Veneziano R, Shepherd TR, Ratanalert S, Bellou L, Tao C, Bathe M. In vitro synthesis of gene-length single-stranded DNA. Sci Rep. 2018;8:1-7.

24. Wang HQ, Deng ZX. Gel electrophoresis as a nanoseparation tool serving DNA nanotechnology. Chin Chem Lett. 2015;26:1435-8.

25. Ture N, Govardhane S, Shende P. Retinoic acid core-shell lipoplexes for the treatment of colorectal cancer. Colloids Surf A Physicochem Eng Asp. 2021;609:125671.

26. Cohen H, Levy RJ, Gao J, Fishbein I, Kousaev V, Sosnowski S, et al. Sustained delivery and expression of DNA encapsulated in polymeric nanoparticles. Gene Ther. 2000;7:1896-905.

27. Prasannaraj G, Sahi SV, Ravikumar S, Venkatachalam P. Enhanced cytotoxicity of biomolecules loaded metallic silver nanoparticles against human liver (HepG2) and prostate (PC3) cancer cell lines. J Nanosci Nanotechnol. 2016;16:4948-59.

28. Um SJ, Han HS, Kwon YJ, Park SH, Rho YS, Sin HS, et al. Novel retinoic acid derivative ABPN has potent inhibitory activity on cell growth and apoptosis in cancer cells. Int $\mathrm{J}$ Cancer. 2003;107:1038-46.

29. Esteves M, Cristóvão AC, Saraiva T, Rocha SM, Baltazar G, Ferreira L, et al. Retinoic acid-loaded polymeric nanoparticles induce neuroprotection in a mouse model for Parkinson's disease. Front Aging Neurosci. 2015;7:20.

30. Varshosaz J, Hassanzadeh F, Sadeghi H, Ghelich Khan Z, Rostami M. Retinoic acid decorated albumin-chitosan nanoparticles for targeted delivery of doxorubicin hydrochloride in hepatocellular carcinoma. J Nanomaterials. 2013;2013:254127. 